\title{
The Knowledge of Antibiotics in Veternary Students and Repercution in Human Health
}

\author{
Silvia D. Peña Betancourt ${ }^{1}$, Silvia Denise Posadas Peña ${ }^{2}$, Lyda Y. Parra-Forero ${ }^{3}$ \\ ${ }^{1}$ Departamento de Producción Agrícola y Animal, Laboratorio de Toxicología, Universidad Autonoma Metropolitana, \\ Ciudad de México, Mexico \\ ${ }^{2}$ Instituto de Estudios Superiores de Monterrey, Ciudad de México, México \\ ${ }^{3}$ Departamento de Producción Agrícola y Animal, Ciudad de México, Mexico \\ Email: spena@correo.xoc.uam.mx, s.denisepp@gmail.com, lyparraf19@gmail.com
}

How to cite this paper: Betancourt, S.D.P., Peña, S.D.P. and Parra-Forero, L.Y. (2020) The Knowledge of Antibiotics in Veternary Students and Repercution in Human Health. Health, 12, 1632-1639.

https://doi.org/10.4236/health.2020.1212119

Received: December 5, 2020

Accepted: December 28, 2020

Published: December 31, 2020

Copyright (c) 2020 by author(s) and Scientific Research Publishing Inc. This work is licensed under the Creative Commons Attribution International License (CC BY 4.0).

http://creativecommons.org/licenses/by/4.0/

(cc) Open Access

\begin{abstract}
The concept of single health is currently undoubtedly one of the most relevant in pandemic times, where humans and animals are together in the same world. Penicillin was discovered in the last century by Alexander Fleming, used against infectious agents mainly of bacterial types, such as Staphylococcus aureus, Corynebacterium, Streptococcus, Brucella and Mycobacterium are examples of cattle pathogens. The bacteria have developed defense mechanisms allowing them to survive in the host cell (mutation) even in the presence of antimicrobials (bacterial selection). The aim of the study was to examine the degree of knowledge of antibiotics through a structured survey of ten questions, addressed to eighty-six students from the Bachelor of Veterinary Medicine and Zootechnics in 2019. Based on the information collected and after analyzing their answers, $63.14 \%$ of the students work in Clinics and Universities, $89.47 \%$ recognize the need for a quantified prescription, $47.36 \%$ mentioned that the Veterinary Medicine can prescribe antimicrobials, 52.63\% support the use of antimicrobials for all microorganisms including viruses, $52.63 \%$ use the labeling to consult the withdrawal time and $100 \%$ identify that it is the withdrawal time and the practices that lead to the development of antimicrobial resistance. It is concluded that most of the students identify malpractice as the trigger for bacterial resistance, however their knowledge is not adequate to avoid antibiotic resistance to humans. It is recommended to reinforce the courses of microbiology, pharmacology and virology in the $\mathrm{Ve}$ terinary Medicine and Zootechnics degree, as well as to be updated on alternatives such as the use of phytobiotics.
\end{abstract}

\section{Keywords}

Antibiotics, Resistance, Bacteria, Veterinary, Students 


\section{Introduction}

The first discovered antibiotic was penicillin by the researcher Alexander Fleming, from a fungus, of the genus Penicillium, which its powerful bactericidal effect was and has been used against Gram+ bacteria. Later, semi-synthetic penicillin such as Ampicillin, Amoxicillin and Cloxacillin, the latter resistant to the "penicillinase" released by Staphylococcus aureus appeared. However, bacteria have developed survival mechanisms such as selection that allows them to infect the host cell and multi-resist antimicrobials [1], such as the case of Mycobacterium tuberculosis, Brucella abortus, Shigella dysenteriae, Listeria monicytogenes and Legionella pneumophila, all with high virulence for cattle. For example, Staphylococcus aureus, the main agent of clinical mastitis, is resistant to Penicillin, Tetracycline and Cephalexin [2].

On the other hand, the transfer of resistant pathogens to humans through the food chain, such as the consumption of meat and milk [3] [4], leads to the misuse of antibiotics in animals, hence, affecting the public health.

According to the European Antimicrobial Consumption Surveillance Office, Spain ranks fifth as a consumer of broad-spectrum penicillin. Besides being considered one of the countries with the highest rates of bacterial resistance and exporter of these resistances worldwide [5] [6].

There are very few works that explore the knowledge about the correct use of antibiotics in those in charge of Animal Health. Therefore, a measure to avoid the misuse of antibiotics is to assess the level of knowledge. In the present study, we conducted a questionnaire to collect information from Veterinary Medicine students and support the subsequent performance of a risk analysis in human health.

\section{Participants}

A cross-sectional descriptive observational study with an analytical component was carried out during 2019, in three groups of students (30 students per group) from the BSc in Veterinary Medicine and Zootechnics. The student's knowledge about antibiotics was considered as the main variable. The structured survey consisted of ten questions that were elaborated as indicators of basic knowledge of the subject, carried out by the National Advisory Technical Council of Animal Health (Table 1). For the descriptive analysis of knowledge, four categories were considered: does not know insufficient knowledge, sufficient knowledge and optimal knowledge. For the data analysis, Microsoft Excel was used and the qualitative variables were expressed as percentages.

\section{Results}

Of the 86 student surveys, the majority answered all questions. The results of the informative indicators note the student status in which $25 \%$ work in veterinary clinics (Figure 1). From their responses, it was observed that $63.14 \%$ of the students work in clinics and universities (Figure 2), 61.45\% recognize that antibiotics 
Table 1. Evaluated indicators in the survey in 2019.

\begin{tabular}{|c|c|c|c|}
\hline $\begin{array}{l}\text { No. } \\
\text { question }\end{array}$ & Question & Possible answers & Knowledge indicator \\
\hline 1 & Occupation & $\begin{array}{l}\text { Veterinary Medicine Student/Intern } \\
\text { Certified veterinarian } \\
\text { Nursing in Veterinary Medicine } \\
\text { Livestock technician }\end{array}$ & Not applicable, informative \\
\hline 2 & Workplace & $\begin{array}{l}\text { Veterinary clinic } \\
\text { Livestock or aquaculture production unit } \\
\text { Universities/Research Center } \\
\text { Manufacturing and marketing companies of } \\
\text { pharmaceutical and food products } \\
\text { Government institution }\end{array}$ & Not applicable, informative \\
\hline 3 & $\begin{array}{l}\text { Type of prescription required for } \\
\text { antimicrobial products due to the level of } \\
\text { risk of the active principle }\end{array}$ & $\begin{array}{l}\text { Quantified } \\
\text { No required prescription } \\
\text { Simple }\end{array}$ & $\begin{array}{l}\text { Sufficient and optimal knowledge } \\
\text { No knowledge } \\
\text { Insufficient knowledge }\end{array}$ \\
\hline 4 & $\begin{array}{l}\text { Licensed veterinarians and interns may } \\
\text { prescribe antimicrobials }\end{array}$ & $\begin{array}{l}\text { True } \\
\text { False }\end{array}$ & Sufficient and optimal knowledge \\
\hline 5 & $\begin{array}{l}\text { Antimicrobials are used to treat the } \\
\text { following microorganisms }\end{array}$ & $\begin{array}{l}\text { Parasites } \\
\text { Bacteria } \\
\text { Mushrooms } \\
\text { Virus } \\
\text { All of the above }\end{array}$ & $\begin{array}{l}\text { Sufficient and optimal knowledge } \\
\text { No knowledge and Insufficient } \\
\text { knowledge }\end{array}$ \\
\hline 6 & $\begin{array}{l}\text { Is antibacterial treatment a good option in } \\
\text { respiratory diseases of viral origin? }\end{array}$ & $\begin{array}{l}\text { True } \\
\text { False }\end{array}$ & $\begin{array}{l}\text { Sufficient and optimal knowledge } \\
\text { No knowledge }\end{array}$ \\
\hline 7 & $\begin{array}{l}\text { What is the means you use most frequently } \\
\text { to check the withdrawal time of } \\
\text { antimicrobials? }\end{array}$ & $\begin{array}{l}\text { Books } \\
\text { Brochures and technical manuals } \\
\text { Scientific articles } \\
\text { Internet } \\
\text { Labelled }\end{array}$ & Not applicable, informative \\
\hline 8 & $\begin{array}{l}\text { Did Mexico sign an agreement declaring the } \\
\text { national strategy of action against } \\
\text { antimicrobial resistance mandatory? }\end{array}$ & $\begin{array}{l}\text { True } \\
\text { False }\end{array}$ & $\begin{array}{l}\text { Sufficient and optimal knowledge } \\
\text { No knowledge }\end{array}$ \\
\hline 9 & $\begin{array}{l}\text { Practices that lead to the development of } \\
\text { antimicrobial resistance in pathogens are }\end{array}$ & $\begin{array}{l}\text { Breach of treatment time } \\
\text { Indiscriminate use of broad-spectrum antimicrobials } \\
\text { Wrong dosage } \\
\text { All of the above }\end{array}$ & $\begin{array}{l}\text { Sufficient and optimal knowledge } \\
\text { No knowledge } \\
\text { Insufficient knowledge }\end{array}$ \\
\hline 10 & $\begin{array}{l}\text { Existing regulation in Mexico that } \\
\text { establishes the guidelines for the } \\
\text { classification and prescription of veterinary } \\
\text { antimicrobials }\end{array}$ & $\begin{array}{l}\text { Agreement declaring the mandatory nature of the } \\
\text { national action strategy against antimicrobial } \\
\text { resistance } \\
\text { NOM-064-ZOO-2000 and the agreement } \\
\text { NOM-040-ZOO-1995 }\end{array}$ & $\begin{array}{l}\text { Sufficient and optimal knowledge } \\
\text { No knowledge } \\
\text { Insufficient knowledge }\end{array}$ \\
\hline 11 & The withdrawal or storage time is & $\begin{array}{l}\text { The time required to reach the ideal weight for } \\
\text { commercialization of the animals } \\
\text { The time established by the farm to comply with the } \\
\text { "all in, all out" system } \\
\text { Comply with the treatment time of the } \\
\text { pharmaceutical product } \\
\text { Allow maximum residue levels to be below those } \\
\text { allowed by the health authority }\end{array}$ & $\begin{array}{l}\text { Sufficient and optimal knowledge } \\
\text { No knowledge } \\
\text { Insufficient knowledge }\end{array}$ \\
\hline
\end{tabular}




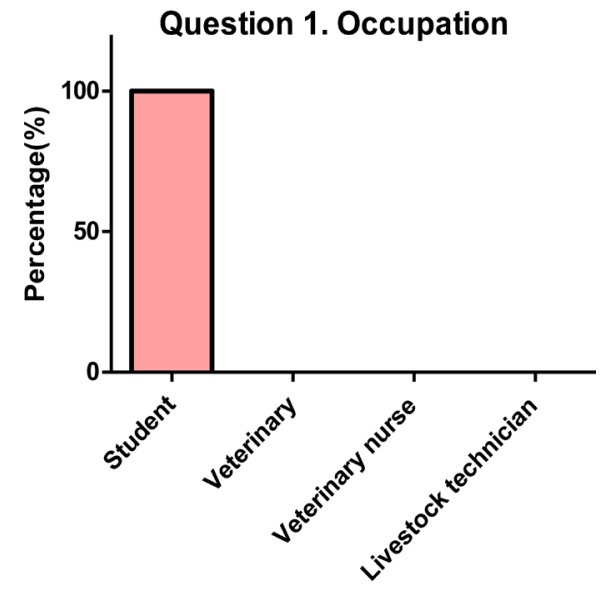

Figure 1. Occupation from the sample population expressed in percentage.

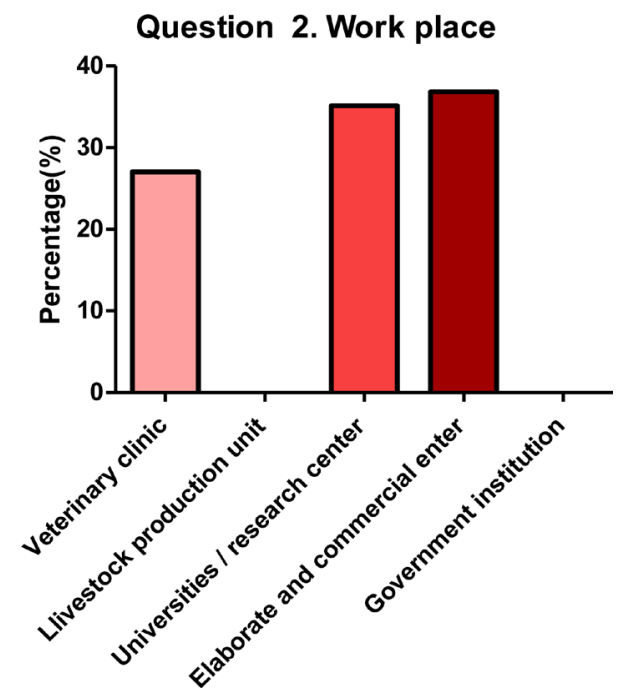

Figure 2. Workplace from the sample population expressed in percentage.

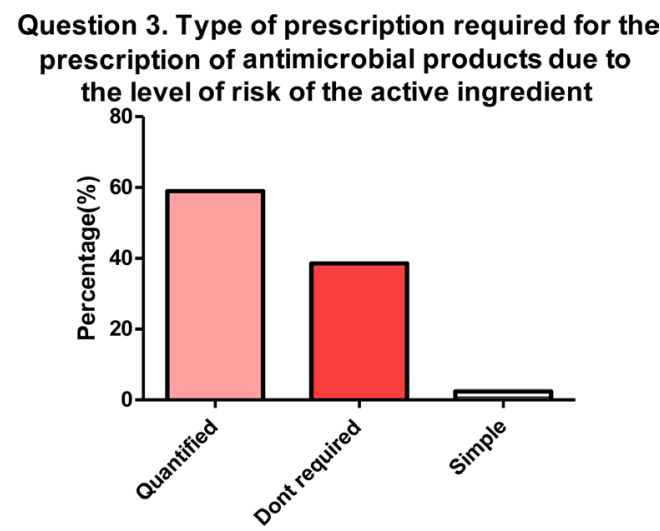

Figure 3. Type of prescription needed according to the sample population expressed in percentage.

should be prescribed by quantified prescription, while $38.55 \%$ do not recognize it as requirement (Figure 3); 48.27\% assure that the Veterinary Medicine intern can prescribe antimicrobials and $51.73 \%$ that a student cannot prescribe antimi- 
crobials (Figure 4); 21.34\% use antimicrobials for all microorganisms including viruses which implies an incorrect knowledge (Figure 5); 20\% possess a poor knowledge about the use of antimicrobials in viral diseases (Figure 6); 18.60\% use the labeling to consult the withdrawal time of antimicrobials (Figure 7) and $88.23 \%$ identify the withdrawal time of an antimicrobial and the practices as factors that lead to the development of resistance to antimicrobials (Figure 8). $20 \%$ of the students have a low knowledge about the withdrawal time that must be respected in antibiotics used for production animals (Figure 9).

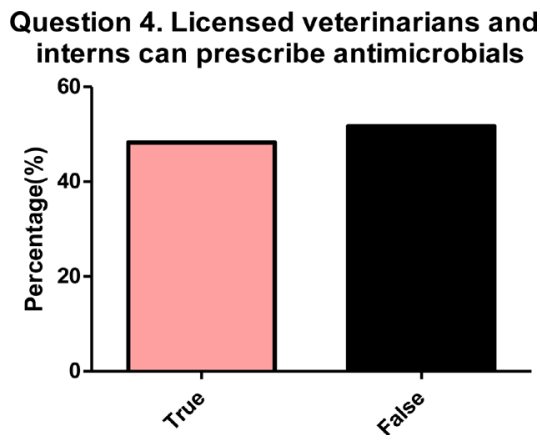

Figure 4. Percentage of the sample population that believe whether a veterinarian can prescribe antimicrobials or not.

\section{Question 5. Antimicrobials are used to treat the following microorganisms}

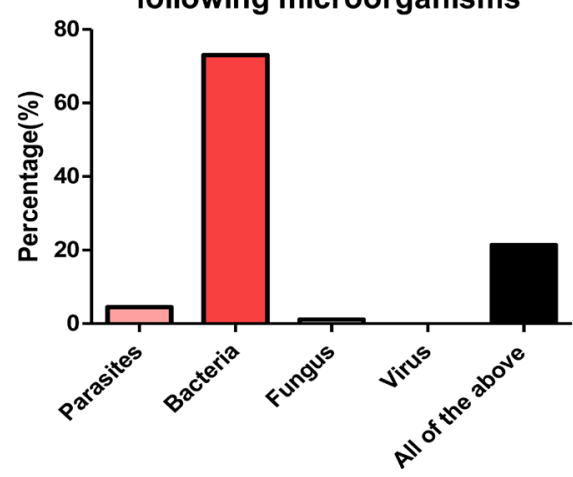

Figure 5. Percentage of the different microorganisms that can be treated by an antimicrobial according to the sample population.

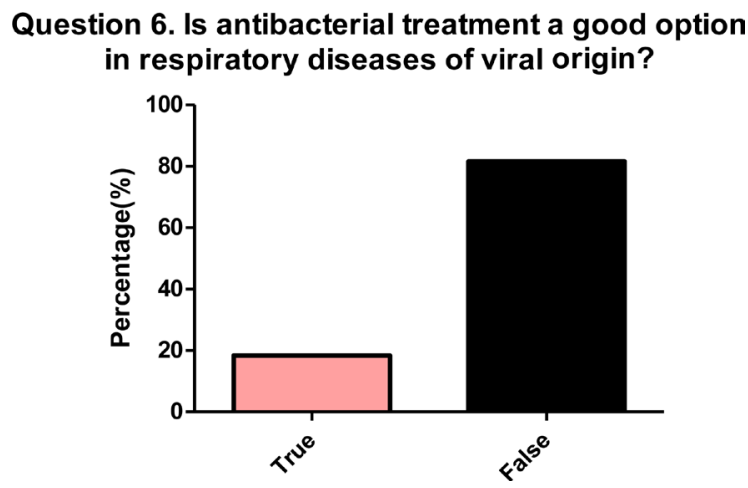

Figure 6. Percentage of the sample population that believes antibacterial treatment can be used for viral diseases. 
Question 7. What is the means you use most frequently to check the withdrawal time of antimicrobials?

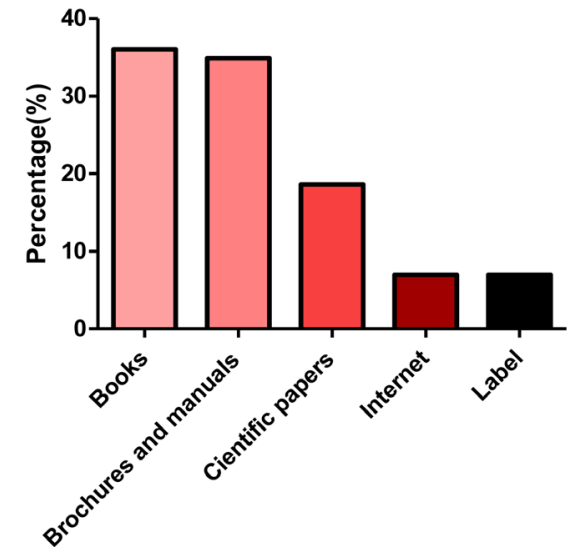

Figure 7. Most used means for withdrawal time expressed in percentage.

Question 9. Practices that lead to the development of antimicrobial resistance in pathogens are:

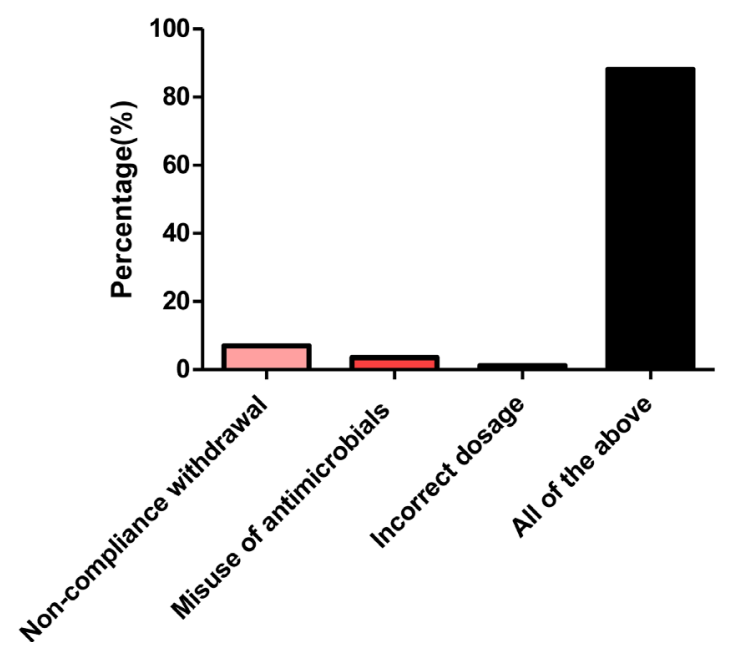

Figure 8. Practices that lead to antimicrobial resistance according to the sample population.

Question 11. Is the withdrawal or storage time?

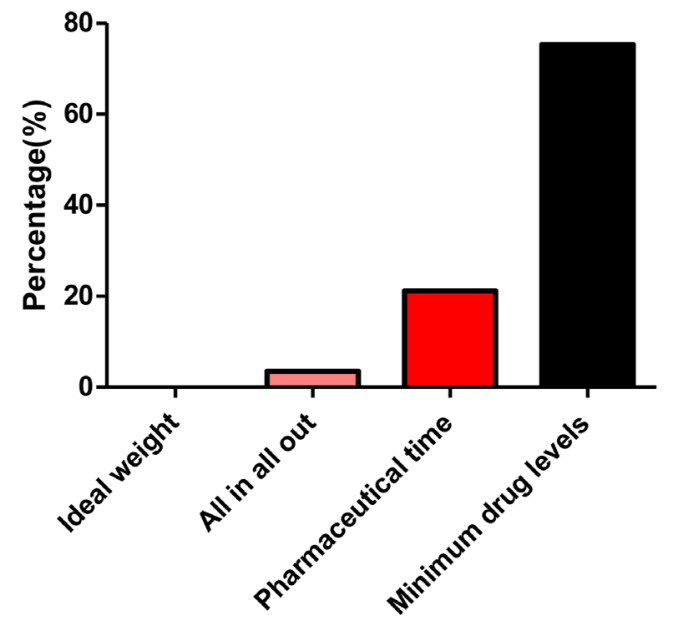

Figure 9. Withdrawal time in antibiotics used for production animals. 


\section{Discussion}

The strategies to identify the knowledge of Veterinary Medicine students about antimicrobials turns out to be a watershed that enables real information in the animal health sector that supports a risk analysis study for human population. One of the most surprising results obtained in the study was the fact of not knowing that antimicrobials are for the exclusive use of bacteria, as identified in students from China by [7]. The authors exonerate the urgency of prioritizing education in health professionals. Hence, the areas of microbiology in the bachelor's study plan as well as pharmacology should be reinforced. If we compare the efforts made in Human Medicine to identify their degree of knowledge in people [8], it can be noted the poor knowledge or ignorance from most of the sample population. In addition, the importance of the veterinarians in animal health and food safety is relevant, as mentioned by [9] [10]. Currently there are advances to establish a rapid and safe diagnosis to identify the pathogenic agent of a disease. For example, molecular methods are available to detect resistance of bacteria to semi-synthetic penicillin, using the blaZ gene and ermC gene [11].

Therefore, an alternative solution to antimicrobial resistance of bacteria according to [12], are natural products. The antimicrobial properties of chemical compounds such as carvacrol, thymol, cineole, linalool, anethole, allicin, capsaicin, allyl isothiocyanate and piperine, have been obtained mainly from oregano, thyme, garlic, cloves, radish, chili, pepper, mint, cinnamon, anise, rosemary and sage [13]

\section{Conclusion}

The administration of antibiotics in production animals has several disadvantages, such as bacterial resistance, which makes disperse into human health. It is estimated that antibiotics will be restricted in most meat and milk importing countries by 2025. Meanwhile, the use of new therapies with products that are harmless to health and the environment should be foreseen. Such is the case of phytobiotics that have given good results as antibacterials.

\section{Conflicts of Interest}

The authors declare no conflicts of interest regarding the publication of this paper.

\section{References}

[1] Munita, J.M. and Arias, C.A. (2016) Mechanisms of Antibiotic Resistance. Microbiology Spectrum, 4, 1-24. https://doi.org/10.1128/microbiolspec.VMBF-0016-2015

[2] Morris, S. and Cerceo, E. (2020) Trends, Epidemiologty and Management of Multi-Drug Resistant Gram Negative Bacterial Infections. Antibiotics, 91, 196. https://doi.org/10.3390/antibiotics9040196

[3] Cota, E., Hurtado, L., Pérez, E. and Alcántara, L. (2014) Resistencia a antibióticos de cepas bacterianas aisladas de animales destinados al consumo humano. Revista Iberoamericana de Ciencias, 1, 75-85. 
[4] Doyle, M. (2012) Veterinary Drug Residues in Processed Meats-Potential Health Risk. Food Research Institute (FRI Briegfings). http://fri.wisc.edu/docs/pdf/t-RIBrief_vetDrgres.pdf

[5] Adriaenssens, N., Coenen, S., Versporten, A., Muller, A., Minalu, G. and Faes, C. (2011) European Surveillance of Antimicrobial Consumption (ESAC): Outpatient Antibiotic Use in Europe (1997-2009). Journal of Antimicrobial Chemotherapy, 6, 3-12. https://doi.org/10.1093/jac/dkr453

[6] Silley, P., Simjee, S. and Schwarz, S. (2012) Surveillance and Monitoring of Antimicrobial Resistance Antibiotic Consumption in Humans and Animals. Revue Scientifique et Technique, 31, 105-120. https://doi.org/10.20506/rst.31.1.2100

[7] Xiao, M.W., Xu, D.Z. and Herskebth, T. (2016) Massive Misuse of Antibiotic by University Students in China. Lancet, 388, S94.

[8] Bernabé, M.E., Macarena Flores, D. and Fernando Martínez M. (2015) Grado de conocimiento del antibiótico prescrito en pacientes ambulatorios. Atención Primaria, 47, 228-235. https://doi.org/10.1016/j.aprim.2014.04.014

[9] García, P., Gastelurrutia, M.A., Baena, M.I., Fisac, F. and Martínez, F. (2009) Validación de un cuestionario para medir el conocimiento de los pacientes sobre sus medicamentos. Atención Primaria, 41, 661-668.

https://doi.org/10.1016/j.aprim.2009.03.011

[10] Kristensson, J., Modig, S., Midlö, P., Rahm, I. and Jakobsson, U. (2010) Health Care Utilisation and Knowledge Concerning Prescribed Drugs among Older People. European Journal of Clinical Pharmacology, 66, 1047-1054.

https://doi.org/10.1007/s00228-010-0837-y

[11] Vieiria, S.Y., Ferreira, M, Boniface, O.L, Godoy, S.F. and Silva M.A. (2019) Characterisation of Antibiotic Resistance Genes in the Species of Rumen Microbiota. Nature Communications, 10, Article No. 5252.

[12] Moore, B.S., Carter, G.T. and Bronshhrup, M. (2017) Are Natural Products the Solution to Antimicrobial Resistance? Natural Product Reports, 34, 685-686. https://doi.org/10.1039/C7NP90026K

[13] Goncagul, G. and Ayaz, E. (2010) Antimicrobial Effect of Garlic (Allium sativum). Recent Patents on Anti-infective Drug discovery, 5, 91-93. https://doi.org/10.2174/157489110790112536 